\title{
The microcirculation: linking trauma and coagulopathy
}

\author{
Kevin R. Ward
}

Survival after severe traumatic shock can be complicated by a number of pathophysiologic processes that ensue after the initial trauma. One of these is trauma-induced coagulopathy (TIC) whose onset may occur before initial fluid resuscitation. The pathogenesis of TIC has not yet been fully elaborated, but evolving evidence appears to link severe tissue hypoxia and damage to the endothelium as key factors, which evolve into measurable structural and biochemical changes of the endothelium resulting in a coagulopathic state. This paper will provide a general review of these linkages and identify knowledge gaps as well as suggest new approaches and areas of investigation, which may both limit the development of TIC as well as produce insights into its pathophysiology. A better understanding of these issues will be necessary in order to advance the practice of remote damage control resuscitation.

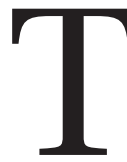

he coagulopathy of trauma, now termed acute traumatic coagulopathy or traumainduced coagulation (TIC), has generally been viewed as resulting from a combination of factors beginning with loss of coagulation factors from hemorrhage, followed by hemodilution by crystalloid resuscitation, and then exacerbated by ensuing acidosis and hypothermia that occurs during the course of ongoing hemorrhage and resuscitation. However, new evidence strongly suggests that TIC begins earlier occurring before fluid resuscitation and without significant consumption of coagulation factors. ${ }^{1}$

From the Department of Emergency Medicine, University of Michigan, Michigan Center for Integrative Research in Critical Care, Ann Arbor, MI.

Address reprint requests to: Kevin R. Ward, MD, Department of Emergency Medicine, University of Michigan, Michigan Center for Integrative Research in Critical Care, NCRC Bldg 26, Office 327N, 2800 Plymouth Road, Ann Arbor, MI 48109; e-mail: keward@umich.edu.

doi: $10.1111 /$ trf. 12034

TRANSFUSION 2013;53:38S-47S.
Early TIC is characterized by anticoagulation and hyperfibrinolysis that is likely modulated through the protein C pathway. Specifically, it has been postulated that thrombin binding to thrombomodulin contributes to hyperfibrinolysis via activated protein $\mathrm{C}$ consumption of plasminogen activator inhibitor-1 (PAI-1). ${ }^{2}$ An increase in thrombomodulin expression on the endothelium complexes with thrombin, which then activates protein C. This complexed thrombin is now no longer available for its usual hemostatic role of cleaving fibrinogen to form fibrin. Subsequent consumption of PAI-1 by activated protein $\mathrm{C}$ contributes to an evolving state of hyperfibrinolysis.

As proposed by Brohi and colleagues, the initiating and perhaps sustaining factor in the development of TIC appears to be severe tissue hypoperfusion and tissue hypoxia. $^{2-4}$ When coagulation has been studied early after trauma, only patients who are in shock as indicated by increased base deficits were noted to have coagulopathy before fluid resuscitation and without the presence of hypothermia. ${ }^{3}$ This is not surprising since severe shock resulting in tissue hypoperfusion as a function of elevated base deficit on admission has been known to be an independent predictor of morbidity and mortality after trauma with this hypoperfusion not necessarily equated with the severity of injury as reflected in Injury Severity Scores. ${ }^{5,6}$

The pathway suggested above also appears logical given the presence of thrombomodulin normally found in the endothelium. Its presence there may be viewed as protective mechanism since it is able to sequester thrombin and thus allow for generation of adequate levels of protein C. This is probably necessary in order to prevent thrombosis in the myriad of conditions that can cause low flow states. However, when this occurs on a mass systemic level as would be expected to occur in severe traumatic shock, this appropriate local response may then become pathologic resulting in a systemic coagulopathic state favoring initial clotting inhibition. While evidence supports that this process occurs in patients with significantly elevated base deficit, the traditional belief that acidosis plays a significant role in TIC is questionable, as recent data demonstrated no significant effect of acidosis on coagulation until $\mathrm{pH}$ becomes less than 7.0. ${ }^{7}$ 


\section{THE MICROCIRCULATION: THE LINK BETWEEN TRAUMA, HYPOPERFUSION, AND TIC?}

Based on the above theory of early TIC causation, it would make great sense to focus on the microcirculation as both a diagnostic and therapeutic target in the prevention and treatment of TIC. The microcirculation with its endothelial lining is estimated to represent an area $4000-7000 \mathrm{~m}^{2}$ and thus is probably best viewed as perhaps the body's largest integrated functional organ system. ${ }^{8,9}$ The individual microcirculatory "unit" composed of the arteriole, capillary bed, and postcapillary venule is designed to ensure the delivery of oxygen and other nutrients to tissues in excess of their needs as well as to remove products of metabolism. The endothelial lining of the microcirculation itself representing some $10^{13}$ cells is a major target of exploration in critical illness and injury, and continued discovery is constantly revealing an ever greater level of complexity in external ultrastructure, cellular makeup, and function. ${ }^{10,11}$ Complicating its understanding in health and disease is the fact that there is no universal phenotype for the endothelium and that this phenotypic heterogeneity is likely to simply be a core property as it is with the parenchymal cells of other organ system. ${ }^{10,11}$ Similar to the parenchymal cellular function of other organ systems, the cells of the vascular endothelium play different roles depending on location. For example, arteriole endothelium plays a major role in regulating vascular tone through a number of mechanisms such as signal transduction to vascular smooth muscle via blood cell to endothelial cell shear stress, while the postcapillary venular endothelium orchestrates leukocyte trafficking in response to various injuries. ${ }^{12}$

Recent attention to the endothelium's glycocalyx structure (a combination of proteoglycans and glycoproteins) and function are now providing important insights into the microcirculatory endothelium's greater role in the development of coagulopathy in response to trauma. ${ }^{13,14} \mathrm{~A}$ delicate and dynamic equilibrium exists between the endothelium glycocalyx and plasma, which normally resist erythrocyte, leukocyte, and thrombocyte interaction between the endothelium. This relationship by its very nature promotes enhanced interaction between the endothelium and plasma itself. It should not then be surprising that injury to the endothelium especially at the level of the microcirculation would be intricately linked to the coagulopathy of trauma. Recent works demonstrating the shedding of syndecan-1 (the major cell membrane protein of the glycocalyx) in response to trauma and hemorrhage and its modulation via different resuscitation strategies favoring plasma to restore the glycocalyx rather than crystalloid are providing tantalizing first insights into the potential for early homeostatic resuscitation and repair of this major organ system. ${ }^{13-19}$ These complex interactions also help in understanding the interactive play and crosstalk between the coagulation and inflammatory systems to an extent that really make the two systems inseparable.

\section{TISSUE HYPOPERFUSION AND THE MICROCIRCULATION: RECIPE FOR INITIATION AND SUSTAINMENT}

The physiologic characteristics of the microcirculation such as the longitudinal oxygen gradients along tissue vascular beds, its lower hematocrit, and thus the heterogeneity of oxygen delivery may make it particularly at risk for hypoxic insults. The TIC described in patients (especially early changes) has been difficult to study in detail. Several factors may be responsible for this including 1) the difficulty in obtaining detailed coagulation parameters and indices in a significant number of traumatically injured patients before traditional fluid resuscitation (traditional crystalloid or massive transfusion protocols); 2) the lack of more early detailed and continuous measures of tissue perfusion; and 3) the lack of high fidelity large animal preclinical models specifically examining coagulation parameters before resuscitation. In regard to this last point, a potentially complicating factor given that swine are the favored large animal model of traumatic shock is the argument that swine are hypercoagulable thus making it more difficult for models utilizing swine to produce coagulation profiles similar to those of humans. ${ }^{20}$ However, new evidence as well as the reiteration of wellknown (but sometimes forgotten) physiologic principles may lend insight into developing preclinical and clinical studies, which may further link the interplay between tissue hypoperfusion, tissue hypoxia, and microcirculatory endothelial damage. Briefly revisiting these concepts may help explain much of the variation reported in animal models and between patients as well as help refocus some of the debate in regard to the value and use of resuscitation protocols such as massive transfusions.

Traditional preclinical models of hemorrhagic shock have utilized the concepts of volume or pressure control hemorrhage and time as a means to control for the severity of hypoperfusion caused by hemorrhage. ${ }^{21}$ Unfortunately, because of the individual compensatory response to trauma, neither of these models results in a uniform metabolic response as indicated by the measure of oxygen debt. As early as the 1960s it has been repetitively shown that hemorrhage to a specific oxygen debt as measured through indirect calorimetry could result is a wide variation of hemorrhage volumes among animals. ${ }^{22-28}$ Oxygen debt is the accumulation of multiple oxygen deficits over time. Oxygen deficit is the difference between basal oxygen consumption and the oxygen consumption at an oxygen delivery level that does not meet aerobic oxygen consumption demands (shock). ${ }^{27}$ To date, oxygen debt is 
the only physiologic measure that has clearly been linked to both mortality and even morbidity in the form of multiple organ failure after shock. ${ }^{27}$ The degree of oxygen debt incurred after injury has also been clearly linked to inflammation. ${ }^{24,29,30}$ This again should not be surprising since in reality oxygen debt can be viewed as a measure of whole body ischemia. While lactate is also a measure of oxygen debt it lacks the precision of indirect calorimetry, and more importantly, because of the biphasic nature of the oxygen delivery and oxygen consumption in regard to critical oxygen delivery (Fig. 1), its resolution during resuscitation does not ensure the important repayment and resolution of oxygen debt. ${ }^{27}$ While the biphasic nature of oxygen delivery and consumption as outlined in Fig. 1 is generally viewed in light of central oxygen transport and hemodynamics, it should be understood that this relationship exists at each individual organ level as is governed in large part at the level of the microcirculation.

Unfortunately, precise measures of oxygen debt in humans using indirect calorimetry require knowledge of baseline oxygen consumption, which itself can vary widely. ${ }^{31,32}$ Since many recent animal laboratory reports examining various blood product resuscitation strategies lack the measure of oxygen debt it is truly difficult to make comparisons of effectiveness both between treatment groups as well as between studies in regard to both the severity of tissue hypoperfusion and the effectiveness in treatments in repaying oxygen debt. ${ }^{33-38}$ In addition, lack of more precise measures of hypoperfusion and tissue hypoxia makes it challenging in exploring the link of these triggers in the development of TIC and its treatment.

Figure 2 provides evidence for the individual variation in response as linked to the microcirculation and to treatment response. Anesthetized swine subjected to soft tissue injury and arterial hemorrhage were monitored for oxygen debt using indirect calorimetry. In addition, the animal's sublingual microcirculation was monitored using sidestream dark-field (SDF) videomicroscopy. ${ }^{39}$ This measure has been demonstrated to track whole body perfusion in sepsis and cardiogenic shock and is now being used to target hemorrhage as changes in the microcirculation have been found to occur earlier than changes in mean arterial pressure in response to central volume changes. ${ }^{40}$ Figure 2A demonstrates the typical swine microcirculation at baseline. Figure $2 \mathrm{~B}$ and $2 \mathrm{C}$ demonstrate the microcirculation of two animals at an oxygen debt accumulation of $80 \mathrm{~mL} / \mathrm{kg}$. The animal from Fig. $2 \mathrm{~B}$ had $30 \%$ of its blood volume removed compared with $50 \%$ of total blood volume removed in the animal pictured in Fig. 2C. In both animals a significant reduction in fibrinogen was noted coupled with a significant reduction in the Maximum Amplitude on thromboelastrography (TEG).

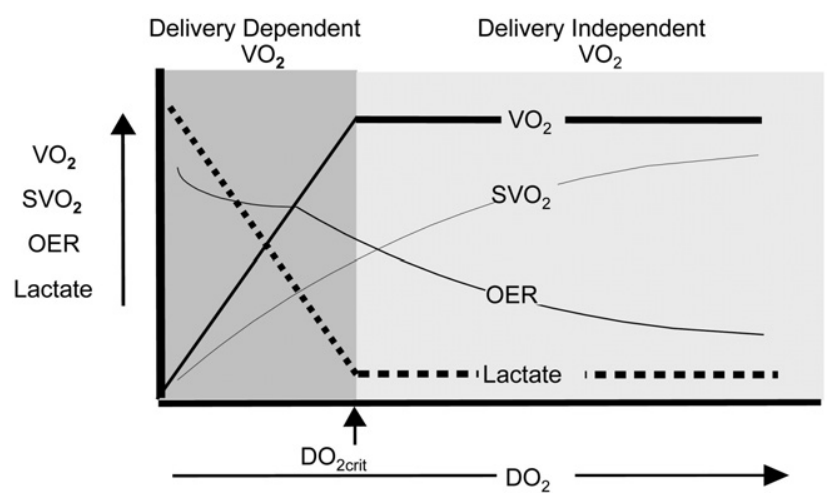

Fig. 1. The biphasic relationship of oxygen delivery $\left(\mathrm{DO}_{2}\right)$ and oxygen consumption $\left(\mathrm{VO}_{2}\right)$. As $\mathrm{DO}_{2}$ decreases, $\mathrm{VO}_{2}$ may remain constant due to an increase in the ratio of extracted oxygen (OER) at the tissue level. This is mirrored by a decrease in venous hemoglobin oxygen saturation $\left(\mathrm{SvO}_{2}\right)$. However, at some point $\mathrm{OER}$ will not meet $\mathrm{VO}_{2}$ demands of the tissues resulting in a state of $\mathrm{DO}_{2}$-dependent $\mathrm{VO}_{2}$ whereby aerobic $\mathrm{VO}_{2}$ transitions to anaerobic $\mathrm{VO}_{2}$. At this point of critical $\mathrm{DO}_{2}$, oxygen debt begins to accumulate along with metabolic byproducts of anaerobiosis such as lactate. While this relationship exists for the body as a whole, it also exists for each individual organ system and is largely mediated by the microcirculation.
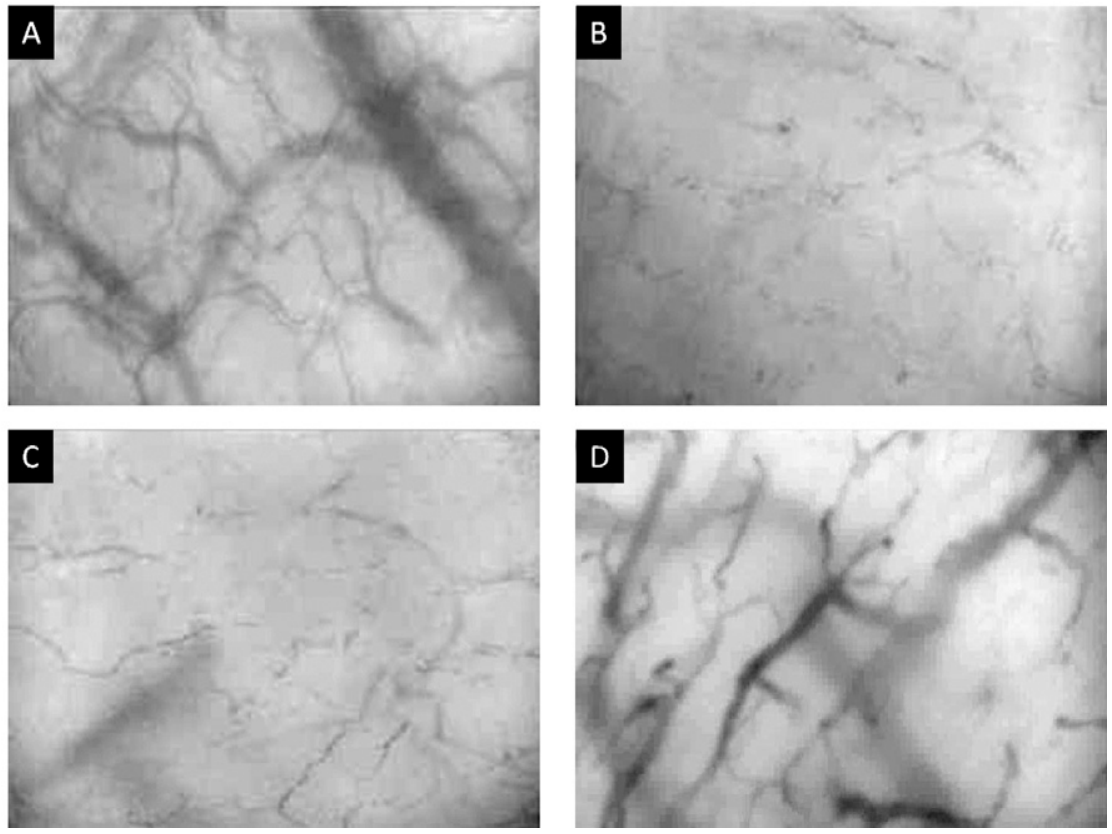

Fig. 2. Microcirculatory images of the swine sublingual surface using sidestream dark-field microscopy at a $167 \times$ magnification. See text for details. 
The animals required 60 and 90 minutes, respectively, to reach an oxygen debt of $80 \mathrm{~mL} / \mathrm{kg}$. The animal in Fig. 2B did not survive a whole blood resuscitation. The animal in Fig. 2C survived but had a rocky course. Finally, the microcirculation pictured in Fig. 2D is from an animal at 1 hour after $50 \%$ blood volume has been removed. This animal had an oxygen debt of $40 \mathrm{~mL} / \mathrm{kg}$ at 60 minutes at which time it was resuscitated with whole blood and easily survived. As can be noted there are striking differences among these three examples in regard to hemorrhage volumes, shock times, oxygen debts, and the microcirculation. This variation from individual to individual in animals is really no different from that in humans. However, as careful inspection of the animal hemorrhagic shock literature would indicate, the compensatory and physiologic reserves of young animals likely require significantly greater insults including the depth of shock to produce metabolic and coagulation abnormalities similar to humans who have less capacity for compensation and are not anesthetized as most animal models are. Rarely is enough attention paid to limit and control for individual variation in animal models of traumatic shock, and evidence exists that if the shock state is deep and controlled enough, coagulopathy begins to develop before treatment. $^{41-43}$

More attention to animal model design and monitoring may provide for new critical insights into the relationship between injury severity, TIC, and its treatment. The importance of this is difficult to overstate especially as more inflammatory and other mediators such as catecholamine levels are being associated with TIC. ${ }^{16-19,44}$ Whether or not they are causal or simply associated with the degree of oxygen debt and thus microcirculatory tissue hypoxia remains to be determined. Even timehonored teachings of the dangers of hypothermia in trauma must be viewed in light of tissue hypoxia since the hypothermia of traumatic shock that is not due to environmental factors is related to the fact that oxygen consumption and temperature are tightly linked through tissue perfusion.

The compilation of these findings coupled with the fact that nonhemorrhage stagnant ischemia and simple hypoxia in cell culture is capable of causing similar damage to the endothelium and its glycocalyx lining, point to tissue hypoxia and a common initiator of microcirculatory endothelium damage. ${ }^{45-48}$ As indicated above, the depth and degree of this hypoxia appear to be critical. However, it is also likely, given the tentacle nature and thickness of the glycocalyx, that the biomechanics of flow may play a role in damage as patients undergoing aortic aneurysm repair under deep hypothermic circulatory arrest and not expected to have typical warm ischemia also demonstrate evidence of endothelial damage by the shedding of syndecan- $1 .{ }^{45}$ Important issues of biomechanical interactions of resuscitation strategies need further investigation given the tremendous differences that likely exist between crystalloid, colloid, and blood component resuscitation ranging from viscosity and rheologic issues to electrostatics and redox potential. ${ }^{49}$ The known surface negative electrostatic charge distribution existing on red and white cells and that of the endothelium cannot be discounted as an important modulator of damage and repair that are linked to tissue hypoxia and flow-related initiators of damage. ${ }^{50-53}$ Lastly, simple mechanical tissue damage itself is likely to play an important role between the microcirculation and TIC if damage is significant enough. This is evidenced by animal models of trauma producing TIC such as Noble-Collip drum shock in which severe tissue injury but not gross hemorrhage is produced. ${ }^{54,55}$ Thus severe soft tissue injury in which a sufficient amount of microvasculature is injured may be capable of producing TIC to a degree similar to severe hemorrhagic shock. A degree of mechanical damage this great would also be expected to result in severe local microcirculatory tissue hypoxia.

\section{TRANSLATIONAL IMPLICATIONS FOR MONITORING AND TREATMENT}

If indeed there is a critical link between tissue hypoperfusion, tissue hypoxia, and TIC, it would seem reasonable to explore and invest in monitoring technologies and strategies that allows for a better early and real-time appreciation of both the degree of shock as well as its resolution as an endpoint. While use of base deficit and lactate as initial screening tools are now fairly ubiquitous for the initial evaluation of the trauma patient, their utility does have some important limitations given the continuum of injury and treatment. As noted in Fig. 1, lactate as an indicator of hypoperfusion and tissue hypoxia rises only after oxygen extraction is maximized by tissues as oxygen consumption becomes directly dependent on oxygen delivery. In addition as patients are resuscitated, anaerobic lactate production will stop once oxygen delivery is above a critical level, and lactate previously produced will begin to be metabolized. However, tissues may still be lacking oxygen delivery levels required to pay back oxygen debt, which may be evidenced by higher than normal levels of oxygen extraction ratios. ${ }^{27}$ Despite this, new point-of-care lactate devices are now available and their distribution and use during the various echelons of care including the prehospital phase of care should be considered as multiple lactate levels over time are more important than single measures. ${ }^{56}$ Thus measures beginning near the time of injury and forward may give a better indication of the degree of accumulated oxygen debt before all-out resuscitation.

Based on the relationship between oxygen delivery, oxygen consumption, and oxygen extraction, the use of tissue hemoglobin oxygen saturation $\left(\mathrm{StO}_{2}\right)$ monitoring is attractive. $\mathrm{StO}_{2}$ monitoring using a number of 
spectroscopy techniques such as near infrared (differential absorption), resonance Raman (vibrational) are being explored as both quantitative shock indicators as well as endpoints of resuscitation. ${ }^{57-60}$ The value of $\mathrm{StO}_{2}$ monitoring is based on the knowledge that for any given volume of tissue, approximately $70 \%-80 \%$ of blood in that tissue resides in the venous compartment while the other $20 \%$ $30 \%$ resides in the arteriolar and capillary compartments. ${ }^{61}$ Thus spectroscopy techniques capable of providing an aggregate measure of hemoglobin $\mathrm{StO}_{2}$ in a segment of tissue provide a value that is dominated by the venous or postextraction component. Because of the biophotonic principles undergirding these measures, $\mathrm{StO}_{2}$ is a reflection of microcirculatory tissue oxygenation. If a tissue bed is chosen that has a reasonable level of basal oxygen extraction and is sensitive to deprivation of blood flow, $\mathrm{StO}_{2}$ may then be able to serve as an early warning indicator of the presence and degree of tissue hypoxia (even before significant changes in vital signs) as well as an endpoint of resuscitation ensuring at least that oxygen extraction levels are not at levels simply above critical oxygen delivery but instead are at levels consistent with normal metabolism and thus perhaps reflective of the repayment of oxygen debt. When used with pulse oximetry, regional oxygen extraction ratios (OER) can be calculated as $\mathrm{SpO}_{2}-\mathrm{StO}_{2} / \mathrm{SpO}_{2}$. This would be similar to systemic (OER) levels using central or mixed venous hemoglobin $\mathrm{StO}_{2}{ }^{32,62}$ Again, certain caveats will apply such as choosing a peripheral tissue site that at least is capable of reflecting whole body changes in OER. Current tissue sites being explored are the skeletal muscle sites in the hand and forearm as well as the buccal mucosa. Use of technologies, such as near infrared spectroscopy for skeletal muscle, presents some challenges, since myoglobin and hemoglobin have identical absorption spectra, which exists in equal concentration gram for gram in tissue but with myoglobin having a significantly lower p50 than hemoglobin (5 mmHg vs. $26 \mathrm{mmHg}$ respectively) ${ }^{63}$ The ability of $\mathrm{StO}_{2}$ to mimic and track changes in central or mixed venous hemoglobin $\left(\mathrm{ScvO}_{2}\right)$ may be important in regard to TIC, since $\mathrm{ScvO}_{2}$ has been demonstrated to be significantly associated with changes in TEG Maximum Amplitude during traumatic shock. ${ }^{64}$ Again, the relationship between $\mathrm{ScvO}_{2}$ and the balance between oxygen consumption and delivery (Fig. 1) as it pertains to oxygen debt make both $\mathrm{ScvO}_{2}$ and its potential surrogate of $\mathrm{StO}_{2}$ attractive. As Fig. 1 would suggest, successful creation and implementation of an $\mathrm{StO}_{2}$ monitor with sufficient sensitivity might allow detection of tissue hypoxia before reaching a level of critical oxygen delivery as well as ensure more complete resuscitation other than simple lactate clearance. Use of $\mathrm{StO}_{2}$ monitoring at earlier echelons of care as a diagnostic and therapeutic endpoint might have great potential to reduce TIC if in fact microcirculatory tissue hypoxia is the link between trauma and TIC. To date, however, $\mathrm{StO}_{2}$ has not been studied as prospective driver of interventions such as transfusion.

The use of SDF microscopy to directly visualize the microcirculation as noted in Fig. 2 is another technology that may provide important diagnostic and therapeutic potential. Using wavelengths of light in the 500-600 nm range (which is absorbed by the red cell hemoglobin independent of oxygenation state) and special optics, this technique allows real-time visualization of the microcirculation in an approximately $1 \mathrm{~mm}^{2}$ field of view and at depths of 100-200 micrometers with $167 \times$ magnification. ${ }^{39,65}$ The resolution of this technique will not, however, allow for visualization of the glycocalyx. The technique can only be used on mucosal surfaces and the vast majority of use has been focused on the easily accessible sublingual mucosa, which appears to be sensitive to a variety of perfusion insults ranging form sepsis to hemorrhage. ${ }^{40,66,67}$ Several perfusion indices have been developed including functional capillary or perfused vessel density and grades of flow. ${ }^{68}$ These indices have shown significant correlation with outcome and treatments. While it has mainly been studied in the setting of sepsis and cardiogenic shock, it is likely to have significant implications in hemorrhage as a means to better detect compensatory states of shock as well as having the potential to be a surrogate for microcirculatory damage and/or ensuring restoration of microcirculatory flow and tissue oxygenation, which are likely to be key in allowing for the repayment of oxygen debt. While better software tools are needed to allow faster and more quantitative image metrics, its use may still allow for important insights. Perhaps its use in preclinical models of traumatic shock might ensure animals all have similar levels of microcirculatory hypoperfusion in order to reduce individual variability.

There are a plethora of other techniques, which may prove to be valuable in the rapid assessment of the patient with traumatic shock. All have their value and basis in microcirculatory blood flow and tissue oxygenation. ${ }^{69}$ These include but are not limited to tissue capnometry (remembering that $\mathrm{CO}_{2}$ production is tightly coupled to oxygen consumption) and new laser Doppler flowmetry techniques. ${ }^{69-71}$ Newer biochemical point-of-care technologies may also prove to be helpful such as inflammatory cytokine markers and, as discussed earlier, even markers specific to the endothelium such as syndecan$1 .{ }^{14,18}$ However, the question as to whether these markers can change early enough to be diagnostically helpful or to guide rapid resuscitation remains to be seen as do their value over other measures of perfusion. The use of measures such as ambient redox potential (the electronic balance between all oxidants and reductants) may prove to be of great utility as there is early evidence that it is linked to both tissue hypoxia and that important mediators of coagulation such as fibrinogen are extremely sus- 
ceptible to oxidative damage, which significantly reduces its function despite having no effect on total fibrinogen levels. ${ }^{72-74}$

Lastly, it is now being suggested that early goaldirected coagulation management of trauma patients takes place using viscoelastic measures of coagulation function such as thromboelastography and that the early use of these measures is predictive of the need for massive transfusion. ${ }^{75,76}$ While this will likely be a very helpful adjunct, based on the evidence and principles discussed above, it should not distract from our developing better real-time measures of tissue perfusion. Again, the developing linkages between tissue hypoxia and TIC would indicate that monitoring for the presence and degree of tissue hypoxia and aggressively treating it to resolution may do the most for both identifying those most at risk for TIC and limiting its development. By doing so, we may be able to better understand by which mechanisms therapies are better able to result in a reduced incidence of TIC. As an example of this, it could be postulated that the better outcomes observed in a number of studies examining the use of massive transfusion protocols result in better outcome simply because the use of whole blood or reconstituted whole blood through the use of component therapy is due to the fact that these may be better resuscitation fluids capable of restoring tissue microcirculatory flow and oxygenation than crystalloids. Conversely these technologies may explain why massive transfusion protocols are not a cure all. Use of such technologies may also allow us to understand which components of fractioned blood (plasma vs. red cells vs. platelets), and in which ratios, may be most helpful while controlling for the initial variation in individual tissue hypoperfusion and hypoxia. ${ }^{77-82}$ Such studies would be informative given suggestions that the combination of colloid resuscitation coupled with fibrinogen and prothrombin complex concentrate may be capable of producing similar outcomes. $^{83-85}$ Since the physiology of casualties will change drastically over short periods of time (especially the more severely injured they are), it will be imperative to study technologies that are capable of detecting and quantifying tissue hypoxia as early after injury as possible in order to ascertain their value for remote damage control resuscitation. In order to do this, technologies will need to be trialed in the prehospital civilian trauma setting before and during resuscitation. To date, no large-scale prehospital trauma tissue perfusion monitoring studies have been reported. Additional challenges in this regard will be the need for miniaturization and ruggedization of such devices, which provide simple and clearly actionable data.

Given the size and phenotypic complexity of the microcirculation and likely similar linkages between tissue hypoxia, coagulation, and inflammation in shock states, a systems biology approach to its study should be considered. ${ }^{86}$ It can be argued that trauma and other shock states result in an endotheliopathy or microcirculopathy. With the advent of high throughput "omic" and computational tools, a rich opportunity exists to study the system in its whole complexity as a physiome if dynamic measures such as flow and oxygenation are included. This would help to ensure that we do not miss important relationships in the network as sadly happens too often in our traditional reductionist approaches.

\section{CONCLUSION}

Mounting evidence links the initial and ongoing systemic microcirculatory tissue hypoperfusion and hypoxia of trauma with the development of TIC. Severe systemic tissue hypoperfusion and hypoxia of the massive organ of the microcirculation likely turns a homeostatic response to tissue hypoperfusion meant to prevent clotting to one of pathogenesis when a critical mass of the microcirculation is injured as would occur in severe traumatic shock. The mechanical and biochemical properties of the mircocirculation and its endothelium appear to put it at particular risk for damage due to hypoperfusion and hypoxia. Renewed emphasis on the development and application of technologies designed to interrogate and report the status of the microcirculation in response to injury and treatment may offer the best hope of mitigating ensuing complications such as TIC by allowing greater insights into presence and depth of tissue hypoxia as well as in developing the best therapies that rapidly restore microcirculatory tissue oxygenation and health.

\section{CONFLICT OF INTEREST}

Dr Ward holds intellectual property in methods of noninvasive monitoring in critical care through Virginia Commonwealth University.

\section{REFERENCES}

1. Floccard B, Rugeri L, Faure A, Saint Denis M, Boyle EM, Peguet O, Levrat A, Guillaume C, Marcotte G, Vulliez A, Hautin E, David JS, Négrier C, Allaouchiche B. Early coagulopathy in trauma patients: an on-scene and hospital admission study. Injury 2012;43:26-32.

2. Brohi K, Cohen MJ, Ganter MT, Matthay MA, Mackersie RC, Pittet JF. Acute traumatic coagulopathy: initiated by hypoperfusion: modulated through the protein $\mathrm{C}$ pathway? Ann Surg 2007;245:812-8.

3. Brohi K, Cohen MJ, Ganter MT, Schultz MJ, Levi M, Mackersie RC, Pittet JF. Acute coagulopathy of trauma: hypoperfusion induces systemic anticoagulation and hyperfibrinolysis. J Trauma 2008;64:1211-7; discussion 1217.

4. Frith D, Davenport R, Brohi K. Acute traumatic coagulopathy. Curr Opin Anaesthesiol 2012;25:229-34. 
5. Davis J, Parks S, Kaups K, Gladen HE, O’Donnell-Nicol S. Admission base deficit predicts transfusion requirements and risk of complications. J Trauma 1996;41:769-74.

6. Rutherford EJ, Morris JA, Jr, Reed GW, Hall KS. Base deficit stratifies mortality and determines therapy. J Trauma 1992; 33:417-23.

7. Engstrom M, Schott U, Romner B, Reinstrup P. Acidosis impairs the coagulation: a thromboelastographic study. J Trauma 2006;61:624-8.

8. Aird WC. Endothelium as an organ system. Crit Care Med 2004;32:S271-9.

9. Trzeciak S, Cinel I, Phillip Dellinger R, Shapiro NI, Arnold RC, Parrillo JE, Hollenberg SM; Microcirculatory Alterations in Resuscitation and Shock (MARS) Investigators. Resuscitating the microcirculation in sepsis: the central role of nitric oxide, emerging concepts for novel therapies, and challenges for clinical trials. Acad Emerg Med 2008;15: 399-413.

10. Aird WC. Phenotypic heterogeneity of the endothelium: II. Representative vascular beds. Circ Res 2007;100:174-90.

11. Aird WC. Phenotypic heterogeneity of the endothelium: I. Structure, function, and mechanisms. Circ Res 2007;100: 158-73.

12. Aird WC. Endothelium in health and disease. Pharmacol Rep 2008;60:139-43.

13. Kozar RA, Peng Z, Zhang R, Holcomb JB, Pati S, Park P, Ko TC, Paredes A. Plasma restoration of endothelial glycocalyx in a rodent model of hemorrhagic shock. Anesth Analg 2011;112:1289-95.

14. Haywood-Watson RJ, Holcomb JB, Gonzalez EA, Peng Z, Pati S, Park PW, Wang W, Zaske AM, Menge T, Kozar RA. Modulation of syndecan-1 shedding after hemorrhagic shock and resuscitation. Plos ONE 2011;6: e23530.

15. Pati S, Matijevic N, Doursout MF, Ko T, Cao Y, Deng X, Kozar RA, Hartwell E, Conyers J, Holcomb JB. Protective effects of fresh frozen plasma on vascular endothelial permeability, coagulation, and resuscitation after hemorrhagic shock are time dependent and diminish between days 0 and 5 after thaw. J Trauma 2010;69(Suppl. 1):S55-63.

16. Johansson PI, Sorensen AM, Perner A, Welling KL, Wanscher M, Larsen CF, Ostrowski SR. High sCD40L levels early after trauma are associated with enhanced shock, sympathoadrenal activation, tissue and endothelial damage, coagulopathy and mortality. J Thromb Haemost 2012;10:207-16.

17. Johansson PI, Stensballe J, Rasmussen LS, Ostrowski SR. High circulating adrenaline levels at admission predict increased mortality after trauma. J Trauma Acute Care Surg 2012;72:428-36.

18. Johansson PI, Stensballe J, Rasmussen LS, Ostrowski SR. A high admission syndecan-1 level, a marker of endothelial glycocalyx degradation, is associated with inflammation, protein $\mathrm{C}$ depletion, fibrinolysis, and increased mortality in trauma patients. Ann Surg 2011;254:194-200.
19. Ostrowski SR, Sorensen AM, Windelov NA, Perner A, Welling KL, Wanscher M, Larsen CF, Johansson PI. High levels of soluble VEGF receptor 1 early after trauma are associated with shock, sympathoadrenal activation, glycocalyx degradation and inflammation in severely injured patients: a prospective study. Scand J Trauma Resusc Emerg Med 2012;20:27.

20. Velik-Salchner C, Schnurer C, Fries D, Müssigang PR, Moser PL, Streif W, Kolbitsch C, Lorenz IH. Normal values for thrombelastography (ROTEM) and selected coagulation parameters in porcine blood. Thromb Res 2006;117:597602.

21. Sondeen JL, Dubick MA, Holcomb JB, Wade CE. Uncontrolled hemorrhage differs from volume- or pressurematched controlled hemorrhage in swine. Shock 2007;28: 426-33.

22. Crowell JW, Smith EE. Oxygen deficit and irreversible hemorrhagic shock. Am J Physiol 1964;206:313-6.

23. Rixen D, Raum M, Holzgraefe B, Sauerland S, Nagelschmidt M, Neugebauer EA; Shock and Trauma Study Group. A pig hemorrhagic shock model: oxygen debt and metabolic acidemia as indicators of severity. Shock 2001; 16:239-44.

24. Rixen D, Siegel JH. Bench-to-bedside review: oxygen debt and its metabolic correlates as quantifiers of the severity of hemorrhagic and post-traumatic shock. Crit Care 2005;9: 441-53.

25. Dunham CM, Siegel JH, Weireter L, Fabian M, Goodarzi S, Guadalupi P, Gettings L, Linberg SE, Vary TC. Oxygen debt and metabolic acidemia as quantitative predictors of mortality and the severity of the ischemic insult in hemorrhagic shock. Crit Care Med 1991;19:231-43.

26. Siegel JH, Fabian M, Smith JA, Kingston EP, Steele KA, Wells MR, Kaplan LJ. Oxygen debt criteria quantify the effectiveness of early partial resuscitation after hypovolemic hemorrhagic shock. J Trauma 2003;54:862-80.

27. Barbee RW, Reynolds PS, Ward KR. Assessing shock resuscitation strategies by oxygen debt repayment. Shock 2010; 33:113-22.

28. Leong B, Reynolds PS, Tiba MH, Holbert WH, Draucker GT, Medina JA, Barbee RW, White NJ, Ward KR. Effects of a combination hemoglobin based oxygen carrier-hypertonic saline solution on oxygen transport in the treatment of traumatic shock. Resuscitation 2011;82:937-43.

29. Siegel JH. Physiologic, metabolic and mediator responses in posttrauma ARDS and sepsis: is oxygen debt a critical initiating factor? J Physiol Pharmacol 1997;48:559-85.

30. Shoemaker WC, Appel PL, Kram HB, Bishop M, Abraham E. Hemodynamic and oxygen transport monitoring to titrate therapy in septic shock. New Horiz 1993;1:145-59.

31. Shoemaker WC, Appel PL, Kram HB. Tissue oxygen debt as a determinant of lethal and nonlethal postoperative organ failure. Crit Care Med 1988;16:1117-20.

32. Chittock DR, Ronco JJ, Russell JA. Monitoring of oxygen transport and oxygen consumption. In: Tobin MJ, editor. 
Principles and practice of intensive care. New York: Mc-Graw Hill, Inc.; 1997. p. 317-43.

33. Alam HB, Bice LM, Butt MU, Cho SD, Dubick MA, Duggan M, Englehart MS, Holcomb JB, Morris MS, Prince MD, Schreiber MA, Shults C, Sondeen JL, Tabbara M, Tieu BH, Underwood SA; Hemostatic Resuscitation Research Group. Testing of blood products in a polytrauma model: results of a multi-institutional randomized preclinical trial. J Trauma 2009;67:856-64.

34. Alam HB, Hamwi KB, Duggan M, Fikry K, Lu J, Fukudome EY, Chong W, Bramos A, Kim K, Velmahos G. Hemostatic and pharmacologic resuscitation: results of a long-term survival study in a swine polytrauma model. J Trauma 2011;70:636-45.

35. Cho SD, Holcomb JB, Tieu BH, Englehart MS, Morris MS, Karahan ZA, Underwood SA, Muller PJ, Prince MD, Medina L, Sondeen J, Shults C, Duggan M, Tabbara M, Alam HB, Schreiber MA. Reproducibility of an animal model simulating complex combat-related injury in a multipleinstitution format. Shock 2009;31:87-96.

36. Shuja F, Shults C, Duggan M, Tabbara M, Butt MU, Fischer TH, Schreiber MA, Tieu B, Holcomb JB, Sondeen JL, Demoya M, Velmahos GC, Alam HB. Development and testing of freeze-dried plasma for the treatment of traumaassociated coagulopathy. J Trauma 2008;65:975-85.

37. Spoerke N, Zink K, Cho SD, Differding J, Muller P, Karahan A, Sondeen J, Holcomb JB, Schreiber M. Lyophilized plasma for resuscitation in a swine model of severe injury. Arch Surg 2009;144:829-34.

38. Sondeen JL, Prince MD, Kheirabadi BS, Wade CE, Polykratis IA, de Guzman R, Dubick MA. Initial resuscitation with plasma and other blood components reduced bleeding compared to hetastarch in anesthetized swine with uncontrolled splenic hemorrhage. Transfusion 2011; 51:779-92.

39. Bezemer R, Bartels SA, Bakker J, Ince C. Clinical review: clinical imaging of the sublingual microcirculation in the critically ill—where do we stand? Crit Care 2012;16:224.

40. Ward KR, Tiba MH, Ryan KL, Filho IP, Rickards CA, Witten T, Soller BR, Ludwig DA, Convertino VA. Oxygen transport characterization of a human model of progressive hemorrhage. Resuscitation 2010;81:987-93.

41. White NJ, Martin EJ, Brophy DF, Ward KR. Coagulopathy and traumatic shock: characterizing hemostatic function during the critical period prior to fluid resuscitation. Resuscitation 2010;81:111-6.

42. White NJ, Martin EJ, Brophy DF, Ward KR. Examining platelet-fibrin interactions during traumatic shock in a swine model using platelet contractile force and clot elastic modulus. Blood Coagul Fibrinolysis 2011;22:379-87.

43. Frith D, Cohen MJ, Brohi K. Animal models of traumainduced coagulopathy. Thromb Res 2012;129:551-6.

44. Johansson PI, Sorensen AM, Perner A, Welling KL, Wanscher M, Larsen CF, Ostrowski SR. Elderly trauma patients have high circulating noradrenaline levels but attenuated release of adrenaline, platelets, and leukocytes in response to increasing injury severity. Crit Care Med 2012;40:1844-50.

45. Rehm M, Bruegger D, Christ F, Conzen P, Thiel M, Jacob M, Chappell D, Stoeckelhuber M, Welsch U, Reichart B, Peter K, Becker BF. Shedding of the endothelial glycocalyx in patients undergoing major vascular surgery with global and regional ischemia. Circulation 2007;116:1896-906.

46. Chappell D, Jacob M, Hofmann-Kiefer K, Rehm M, Welsch $\mathrm{U}$, Conzen P, Becker BF. Antithrombin reduces shedding of the endothelial glycocalyx following ischaemia/ reperfusion. Cardiovasc Res 2009;83:388-96.

47. Mulivor AW, Lipowsky HH. Inflammation- and ischemiainduced shedding of venular glycocalyx. Am J Physiol Heart Circ Physiol 2004;286:H1672-80.

48. Platts SH, Linden J, Duling BR. Rapid modification of the glycocalyx caused by ischemia-reperfusion is inhibited by adenosine A2A receptor activation. Am J Physiol Heart Circ Physiol 2003;284:H2360-7.

49. Resnick N, Yahav H, Shay-Salit A, Shushy M, Schubert S, Zilberman LC, Wofovitz E. Fluid shear stress and the vascular endothelium: for better and for worse. Prog Biophys Mol Biol 2003;81:177-99.

50. Oka S. Physical theory of some interface phenomena in hemorheology. Ann N Y Acad Sci 1983;416:115-27.

51. Gorog P, Schraufstatter I, Born GV. Effect of removing sialic acids from endothelium on the adherence of circulating platelets in arteries in vivo. Proc R Soc Lond B Biol Sci 1982;214:471-80.

52. Born GV, Palinski W. Increased microvascular resistance to blood flow in the rat hindlimb after perfusion with neuraminidase. J Physiol 1989;419:169-76.

53. Vink H, Wieringa PA, Spaan JA. Evidence that cell surface charge reduction modifes capillary red cell velocity-flux relationships in hamster cremaster muscle. J Physiol 1995; 489:Pt 1): 193-201.

54. Tanabe K, Yoshitake J. [A study on coagulative and fibrinolytic dynamics in experimental traumatic shock (author's transl)]. Masui 1981;30:826-31.

55. Kugimiya H. [A pathophysiological and biochemical study of the experimental traumatic shock in rats-a relationship between coagulation/fibrinolytic system and DIC (author's transl)]. Masui 1982;31:75-84.

56. Reynolds PS, Barbee RW, Ward KR. Lactate profiles as a resuscitation assessment tool in a rat model of battlefield hemorrhage-resuscitation. Shock 2008;30:48-54.

57. Soller BR, Zou F, Ryan KL, Rickards CA, Ward K, Convertino VA. Lightweight noninvasive trauma monitor for early indication of central hypovolemia and tissue acidosis: a review. J Trauma Acute Care Surg 2012;73:S106-11.

58. Ward KR, Torres Filho I, Barbee RW, Torres L, Tiba MH, Reynolds PS, Pittman RN, Ivatury RR, Terner J. Resonance Raman spectroscopy: a new technology for tissue oxygenation monitoring. Crit Care Med 2006;34:792-9.

59. Crookes BA, Cohn SM, Bloch S, Amortegui J, Manning R, Li P, Proctor MS, Hallal A, Blackbourne LH, Benjamin R, 
Soffer D, Habib F, Schulman CI, Duncan R, Proctor KG. Can near-infrared spectroscopy identify the severity of shock in trauma patients? J Trauma 2005;58:806-13. discussion 813-6.

60. Moore FA, Nelson T, McKinley BA, Moore EE, Nathens AB, Rhee P, Puyana JC, Beilman GJ, Cohn SM; $\mathrm{StO}_{2}$ Study Group. Massive transfusion in trauma patients: tissue hemoglobin oxygen saturation predicts poor outcome. J Trauma 2008;64:1010-23.

61. Shepherd JT. Circulation to skeletal muscle. In: Shepherd JT, Abboud FM, Geiger SR, editors. Handbook of physiology. Bethesda (MD): American Physiology Society; 1983. p. 319-70.

62. Hogan CJ, Ward KR, Kontos MC, Thacker LR, Pittman R. Peripheral tissue oxygenation improves during ED treatment of acute heart failure. Am J Emerg Med 2012;30:196202.

63. Ward KR, Ivatury RR, Barbee RW, Terner J, Pittman R, Filho IP, Spiess B. Near infrared spectroscopy for evaluation of the trauma patient: a technology review. Resuscitation 2006;68:27-44.

64. White NJ, Martin EJ, Shin Y, Brophy DF, Diegelmann RF, Ward KR. Systemic central venous oxygen saturation is associated with clot strength during traumatic hemorrhagic shock: a preclinical observational model. Scand J Trauma Resusc Emerg Med 2010;18:64.

65. Buchele GL, Ospina-Tascon GA, De Backer D. How microcirculation data have changed my clinical practice. Curr Opin Crit Care 2007;13:324-31.

66. De Backer D, Creteur J, Dubois MJ, Sakr Y, Vincent JL. Microvascular alterations in patients with acute severe heart failure and cardiogenic shock. Am Heart J 2004;147: 91-9.

67. De Backer D, Creteur J, Preiser JC, Dubois MJ, Vincent JL. Microvascular blood flow is altered in patients with sepsis. Am J Respir Crit Care Med 2002;166: 98-104.

68. De Backer D, Hollenberg S, Boerma C, Goedhart P, Büchele G, Ospina-Tascon G, Dobbe I, Ince C. How to evaluate the microcirculation: report of a round table conference. Crit Care 2007;11:R101.

69. Ward KR, Ivatury RR, Barbee RW. Endpoints of resuscitation for the victim of trauma. J Intensive Care Med 2001;16: 55-75.

70. De Backer D, Donadello K, Cortes DO. Monitoring the microcirculation. J Clin Monit Comput 2012;26: 361-6.

71. De Backer D, Ospina-Tascon G, Salgado D, Favory R, Creteur J, Vincent JL. Monitoring the microcirculation in the critically ill patient: current methods and future approaches. Intensive Care Med 2010;36:1813-25.

72. White N, Collinson M, Boe R, Ward K. Redox monitoring reveals increased suspectibility of whole blood to oxidative stress during hemorrhagic shock [abstract]. Circulation 2008;2008:S-1488.
73. White N, Collinson M, Mir A, Ward K. Whole blood redox potential correlates with total body oxygen consumption during hermorrhagic shock and resuscitation [abstract]. Acad Emerg Med 2009;16:S6.

74. White N, Collinson M, Mir A, Ward K. Whole blood redox potential correlates with fibrinogen concentration during hemorrhagic shock. Shock 2009;31:P47.

75. Schochl H, Nienaber U, Hofer G, Voelckel W, Jambor C, Scharbert G, Kozek-Langenecker S, Solomon C. Goaldirected coagulation management of major trauma patients using thromboelastometry (ROTEM)-guided administration of fibrinogen concentrate and prothrombin complex concentrate. Crit Care 2010;14:R55.

76. Holcomb JB, Minei KM, Scerbo ML, Radwan ZA, Wade CE, Kozar RA, Gill BS, Albarado R, McNutt MK, Khan S, Adams PR, McCarthy JJ, Cotton BA. Admission rapid thrombelastography can replace conventional coagulation tests in the emergency department: experience with 1974 consecutive trauma patients. Ann Surg 2012;256:476-86.

77. Brasel KJ, Vercruysse G, Spinella PC, Wade CE, Blackbourne LH, Borgman MA, Zarzabal LA, Du F, Perkins JG, Maegele M, Schreiber M, Hess JR, Jastrow KM 3rd, Gonzalez EA, Holcomb JB, Kozar R; Trauma Outcomes Group; Brasel KJ, Vercruysse G, MacLeod J, Dutton RP, Duchesne JC, McSwain NE, Muskat P, Johannigamn J, Marin B, et al. The association of blood component use ratios with the survival of massively transfused trauma patients with and without severe brain injury. J Trauma 2011;71:S343-52.

78. Brown LM, Aro SO, Cohen MJ; Trauma Outcomes Group; Holcomb JB, Wade CE, Brasel KJ, Vercruysse G, MacLeod J, Dutton RP, Hess JR, Duchesne JC, McSwain NE, Muskat P, Johannigamn J, Cryer HM, Tillou A, Pittet JF, Knudson P, De Moya MA, Schreiber MA, Tieu B, Brundage S, Napolitano LM, Brunsvold M, Marin B, et al. A high fresh frozen plasma: packed red blood cell transfusion ratio decreases mortality in all massively transfused trauma patients regardless of admission international normalized ratio. J Trauma 2011;71:S358-63.

79. Rowell SE, Barbosa RR, Diggs BS, Schreiber MA; Trauma Outcomes Group; Holcomb JB, Wade CE, Brasel KJ, Vercruysse G, MacLeod J, Dutton RP, Hess JR, Duchesne JC, McSwain NE, Muskat P, Johannigamn J, Cryer HM, Tillou A, Cohen MJ, Pittet JF, Knudson P, De Moya MA, Schreiber MA, Tieu B, Brundage S, Marin B, et al. Effect of high product ratio massive transfusion on mortality in blunt and penetrating trauma patients. J Trauma 2011;71:S353-7.

80. Sambasivan CN, Kunio NR, Nair PV, Zink KA, Michalek JE, Holcomb JB, Schreiber MA; Trauma Outcomes Group; Wade CE, Brasel KJ, Vercruysse G, MacLeod J, Dutton RP, Hess JR, Duchesne JC, McSwain NE, Muskat P, Johannigamn J, Cryer HM, Tillou A, Cohen MJ, Pittet JF, Knudson P, De Moya MA, Tieu B, Marin B, et al. High ratios of plasma and platelets to packed red blood cells do not affect mortality in nonmassively transfused patients. J Trauma 2011;71:S329-36. 
81. Spoerke N, Michalek J, Schreiber M; Trauma Outcomes Group; Brasel KJ, Vercruysse G, MacLeod J, Dutton RP, Duchesne JC, McSwain NE, Muskat P, Johannigamn J, Cryer HM, Tillou A, Cohen MJ, Pittet JF, Knudson P, De Moya MA, Tieu B, Brundage S, Napolitano LM, Brunsvold M, Sihler KC, Peitzman AB, Zenait MS, Marin B, et al. Crystalloid resuscitation improves survival in trauma patients receiving low ratios of fresh frozen plasma to packed red blood cells. J Trauma 2011;71:S380-3.

82. Wade CE, del Junco DJ, Holcomb JB; Trauma Outcomes Group; Holcomb JB, Wade CE, Brasel KJ, Vercruysse G, MacLeod J, Dutton RP, Hess JR, Duchesne JC, McSwain NE, Muskat P, Johannigman J, Cryer HM, Tillou A, Cohen MJ, Pittet JF, Knudson P, De Moya MA, Schreiber MA, Tieu B, Brundage S, Napolitano LM, Marin B, et al. Crystalloid resuscitation improves survival in trauma patients receiving low ratios of fresh variations between level I trauma centers in 24-hour mortality in severely injured patients requiring a massive transfusion. J Trauma 2011;71: S38993.

83. Fries D, Innerhofer P, Perger P, Gütl M, Heil S, Hofmann N, Kneifel W, Neuner L, Pernerstorfer T, Pfanner G, Schöchl H, Ziegler B, Kölblinger C, Kozek-Langenecker S. [Coagulation management in trauma-related massive bleeding. Recommendations of the Task Force for Coagulation (AGPG) of the Austrian Society of Anesthesiology, Resuscitation and Intensive Care Medicine (OGARI)]. Anasthesiol Intensivmed Notfallmed Schmerzther 2010;45:55261.

84. Fries D, Martini WZ. Role of fibrinogen in trauma-induced coagulopathy. Br J Anaesth 2010;105:116-21.

85. Sorensen B, Fries D. Emerging treatment strategies for trauma-induced coagulopathy. Br J Surg 2012;99(Suppl. 1):40-50.

86. Clermont G, Neugebauer EA. Systems biology and translational research. J Crit Care 2005;20:381-2. 